\section{Influence of Cultivar, Growing Media, and Cluster Pruning on Greenhouse Tomato Yield and Fruit Quality}

\author{
Hanna Y. Hanna ${ }^{1}$
}

ADDITIONAL INDEX WORDs. Solanum lycopersicum, perlite, pine bark, rockwool

SuMMARY. Cultivars and growing media are important components of a successful greenhouse tomato (Solanum lycopersicum) operation. Two studies were conducted simultaneously and independently in two $30 \times 96-\mathrm{ft}$ greenhouses in Spring 2006 and 2007 (January-July) to assist producers in selecting appropriate cultivars and reducing production cost. The first study was conducted to evaluate yield, fruit weight, fruit quality, and shelf life of 'Geronimo', 'Quest', and 'Trust' tomatoes planted in perlite and pruned to three or four fruit per cluster. The second study was conducted to determine the initial cost of perlite, pine bark, and rockwool growing media and their effect on yield of 'Quest' pruned to three or four fruit per cluster. 'Geronimo' produced the highest total marketable yield and 'Trust' produced the lowest. 'Trust' produced more cull yield and lower fruit weight than 'Geronimo' or 'Quest'. Pruning clusters to three fruit increased total marketable yield and fruit weight, and reduced cull yield of all cultivars. Only 'Geronimo' produced higher early marketable yield at four fruit per cluster. All cultivars produced higher early marketable yield in 2007 than in 2006. Tested cultivars had similar fruit content of potassium and sodium and similar concentration of soluble solids. 'Trust' fruit had a higher $\mathrm{pH}$ than the other two cultivars. About $92 \%$ of 'Quest' tomatoes remained marketable after storage at $67^{\circ} \mathrm{F}$ for 1 week. 'Geronimo' and 'Trust' had only $83 \%$ and $78 \%$ marketable fruit, respectively, under the same conditions. Initial costs to grow greenhouse tomatoes in perlite were higher than in rockwool, and were the lowest in pine bark. Plants grown in perlite produced higher total marketable yield than plants grown in either of the other media. They produced lower cull yield than plants grown in rockwool, but produced similar cull yield to plants grown in pine bark. Pruning clusters to three fruit increased total marketable yield and fruit weight in both studies. Pruning clusters to four fruit increased cull yield in both studies regardless of planting year.

S mall greenhouse tomato operations are common in the United States (Korevaar, 2007; Snyder, 1995). Transportation expenses are now accounting for a substantial part of tomato production costs. This factor provides new opportunities for marketing locally produced tomatoes at a reasonable price. Growers can produce an attractive fruit to be sold on the day of harvest at producer premises, farmers markets, road-side stands, and local grocery stores. However, they have to reduce production costs and increase plant yield to gain a fair market share among major producers.

Previous research has indicated that perlite growing media can be recycled to save money (Hanna, 2005, 2006), and precision heating can reduce production costs (Hanna

Louisiana State University Agricultural Center, Red River Research Station, 262 Research Station Drive, Bossier City, LA 71112

${ }^{1}$ E-mail: hhanna@agcenter.lsu.edu. and Henderson, 2002, 2008). Other production practices need to be reexamined to enhance yield and further reduce costs.

The choice of an adequate-yielding tomato cultivar with desired fruit qualities and longer shelf life is a vital grower decision. Failure to select an appropriate cultivar may lead to lower yield or less market acceptability (Hochmuth, 1991; Maynard and Olson, 2002; Papadopoulos, 1991; Snyder, 2001). 'Trust' was among the most recommended cultivars in
Mississippi (Snyder, 1995) and was popular in Louisiana, Texas, and Alabama (Mississippi Tomato Short Course, unpublished data); however, fruit shelf life was short because of moisture loss through fine cracks on fruit shoulder (Fig. 1). Newer cultivars such as Geronimo and Quest need to be evaluated for yield, fruit quality, and shelf life.

Producers use rockwool as growing media in large commercial operations around the world (Papadopoulos, 1991). Most Mississippi growers use locally produced pine bark that has been finely shredded and composted for at least 3 months (Snyder, 2001). Perlite is another growing medium used for growing greenhouse tomatoes in Europe and North America (Szmidt et al., 1988). Growers need to be informed about the initial cost of these media and their impact on tomato yield.

The North American market demands large fruit (Korevaar, 2007). Cultivar and fruit number per cluster affect fruit weight. Fruit pruning is used to limit the number of fruit per cluster and reduce competition to increase fruit weight. Demers et al. (2007) recommended pruning 'Beefsteak'-type cultivars grown under southwestern Ontario conditions to three fruit in early spring and late fall and to five fruit during the summer. The Ministry of Agriculture, Food, and Rural Affairs in Canada (2001) recommended pruning 'Beefsteak'type cultivars to four fruit per cluster. Papadopoulos (1991) recommended pruning the first two clusters to three fruit and later clusters to four fruit. Hochmuth (1991) indicated that cultivars capable of producing large fruit should be pruned to three or four fruit per cluster if the grower's goal was to produce large fruit. Snyder (2001) recommended pruning clusters to three, four, or five fruit. Yield

\begin{tabular}{llll}
\hline $\begin{array}{l}\text { Units } \\
\text { To convert U.S. to SI, } \\
\text { multiply by }\end{array}$ & U.S. unit & SI unit & $\begin{array}{l}\text { To convert SI to U.S., } \\
\text { multiply by }\end{array}$ \\
\hline 29.5735 & $\mathrm{fl} \mathrm{oz}$ & $\mathrm{mL}$ & 0.0338 \\
0.3048 & $\mathrm{ft}$ & $\mathrm{m}$ & 3.2808 \\
0.0283 & $\mathrm{ft}^{3}$ & $\mathrm{~m}^{3}$ & 35.3147 \\
3.7854 & gal & $\mathrm{L}$ & 0.2642 \\
2.54 & inch $(\mathrm{es})$ & $\mathrm{cm}$ & 0.3937 \\
0.4536 & $\mathrm{lb}$ & $\mathrm{kg}$ & 2.2046 \\
28.3495 & $\mathrm{Oz}$ & $\mathrm{g}$ & 0.0353 \\
1 & $\mathrm{ppm}$ & $\mathrm{mg} \cdot \mathrm{L}^{-1}$ & 1 \\
$\left({ }^{\circ} \mathrm{F}-32\right) \div 1.8$ & ${ }^{\circ} \mathrm{F}$ & ${ }^{\circ} \mathrm{C}$ & $\left(1.8 \times{ }^{\circ} \mathrm{C}\right)+32$
\end{tabular}



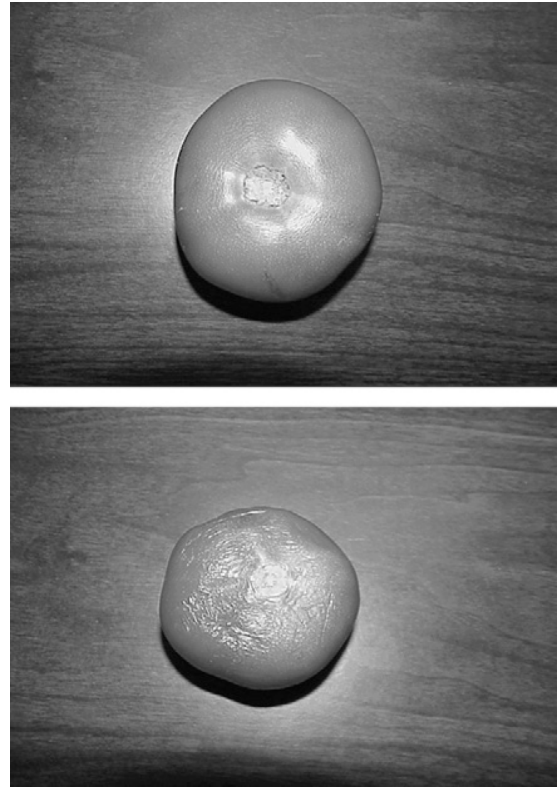

Fig. 1. 'Trust' tomato fruit with fine shoulder cracks (top) and wrinkled shoulder (bottom) as a result of moisture loss through the fine shoulder cracks after being stored for 1 week at $67^{\circ} \mathrm{F}\left(19.4{ }^{\circ} \mathrm{C}\right)$ average day and night temperature.

response to these pruning methods was not clearly documented.

The objectives of this study were to evaluate the yield, fruit weight, fruit quality, and shelf life of 'Geronimo', 'Quest', and 'Trust' planted in perlite and pruned to three or four fruit per cluster, and to determine the initial cost of perlite, pine bark, and rockwool growing media and their effect on the yield of 'Quest' pruned to three or four fruit per cluster.

\section{Materials and methods}

Two studies were conducted simultaneously and independently in Spring 2006 and 2007 (January-July) in two identical $30 \times 96-\mathrm{ft}$ greenhouses. The greenhouses were covered with a double layer of polyethylene and were used to grow 640 tomato plants in 320 polyethylene 5-gal upright grow bags at Louisiana State University Agricultural Center in Bossier City. Each grow bag measured 13 inches in diameter and 10 inches in height and had holes at the bottom and sides to drain excess nutrient solution.

In the first study, 'Geronimo', 'Quest', and 'Trust', selected from among 10 greenhouse cultivars previously evaluated in our observational trials, were planted in the grow bags filled with perlite (BWI, Texarkana, TX). 'Geronimo' was selected because it produced high yields, 'Quest' was selected for its shiny fruit, and 'Trust' was selected because it was popular among growers in Mississippi and Louisiana. 'Geronimo' and 'Quest' were newer cultivars than 'Trust' (Deruter Seeds, Columbus, $\mathrm{OH}$ ). Transplants from all three cultivars were grown in plastic trays with 38 cells (Growing System, Milwaukee, WI) filled with the soilless mix ProMix BX (Premier Horticulture, Quakertown, PA) for 5 weeks before being planted in the grow bags. Two transplants were planted at 3 -inch depth and spaced 7 inches apart in each bag. Using the V-shape method, plants were spaced 17 inches apart within the row and rows were spaced $3 \mathrm{ft}$ apart at the overhead supporting wire. The greenhouse had 10 rows of plants with north/south orientation. Other cultural practices consisted of standard recommendations for growing greenhouse tomatoes for fresh market production in Louisiana (Hanna, 2003).

The experiment was a $3 \times 2$ factorial of cultivar (Geronimo, Quest, and Trust) and cluster pruning (three or four fruit per cluster) in a randomized complete block design with three replications (plots) of 10 plants. Clusters were pruned to remove excess fruit and flower as soon as three or four fruit per cluster were visible in each respective treatment. Three to five ripe fruit having similar color and size were selected from each plot of the three fruit per cluster treatment at early, mid, and end of harvest season for fruit analysis. Fruit were placed in a food processor (Waring Commercial, Atlanta, GA) after being sliced to small wedges. The food processor was operated at high speed until all fruit tissue reached a liquid form (Morgan, 2001). About $0.3 \mathrm{~mL}$ of the mixed solution was placed onto the prism surface of pocket digital refractometer (Pal-1; Atago, Tokyo) and soluble solids concentration was recorded. Fruit potassium and sodium contents were determined using Cardy ion meters (Horiba Instruments, Irvine, CA). Fruit $\mathrm{pH}$ was determined using a $\mathrm{pH}$ meter (mini Laboratory; IQ Scientific Instruments, San Diego, CA). Because fruit analysis data for each harvest date were similar, an average season analysis was recorded.
About $10 \mathrm{lb}$ of marketable fruit were harvested weekly from each plot of the three fruit per cluster treatment, packed in a tomato carton box, and stored for 1 week in a cooled room at $67^{\circ} \mathrm{F}$ average day and night temperatures (Newsom, 1961). To determine the percentage of fruit that remained marketable after the storage period, fruit were evaluated visually by two experienced workers who had hand-packed tomatoes in comparable boxes during the past 10 years. Firm fruit with no skin discoloration, shrinking, or deterioration were considered marketable. The sum of marketable and unmarketable fruit for the entire season was determined, and the percentage of marketable fruit was calculated.

In the second study, a $3 \times 2$ factorial experiment was conducted in a randomized complete block design to determine the effects of perlite, pine bark, and rockwool growing media and pruning clusters to three or four fruit on 'Quest' yield. Transplants were grown and planted in grow bags filled with perlite or pine bark (Lowe's, North Wilkesboro, NC) as described earlier. Transplants for the rockwool treatment were grown in rockwool cubes for 5 weeks before being planted in rockwool slabs (Grodan, Coppell, TX). Retail cost of growing media, transplant media, and containers to grow 640 plants in one greenhouse was determined based on invoices received from supplier companies.

Tomatoes were harvested from each treatment in both tests at the pink stage three times per week for 19 weeks. Fruit with blossom-end rot and other defects were removed, and the remainder were graded according to U.S. Department of Agriculture standards (USDA, 1997). Early marketable yield was determined by weighing fruit graded medium or larger in the first five harvests. Total marketable yield was determined by weighing fruit graded medium or larger in all harvests. Cull yield was the weight of all fruit with visible defects and small size. Mean fruit weight was determined on all marketable fruit.

Data for both studies were analyzed as a randomized complete block design with three replications using the PROC MIXED procedure of SAS (version 9.1.3; SAS Institute, Cary, 
NC). Blocks (replications) nested within years were considered random, and cultivars and pruning methods were considered fixed. Levels of significance of the main effects and interactions in the analysis of variance table were determined with the F test. When significant interactions were found, means separation was performed using the SLICE option of the least square means. Means separation of the main effects was conducted using the DIFF option of the least square means.

\section{Results and discussion}

In the first study, the effects of cultivar and cluster pruning on early and total marketable yields, cull yield, and fruit weight were significant except pruning effect on early marketable yield as indicated by the F test and mean separation data in Table 1. Cultivar $\times$ pruning and cultivar $\times$ year interactions were significant for early marketable yield, and pruning $\times$ year interaction was significant for cull yield (Table 1). Further data analysis of interactions revealed that 'Geronimo' was the only cultivar that produced higher early marketable yield at four fruit per cluster (Table 2). All cultivars produced significantly higher

Table 1. Analysis of variance and mean separation by least square means for tomato marketable and cull yields and fruit weight in 2006 and 2007 as related to treatment effect in a $30 \times 96-\mathrm{ft}(9.1 \times 29.3 \mathrm{~m})$ greenhouse at Louisiana State University Agricultural Center, Bossier City.

\begin{tabular}{|c|c|c|c|c|}
\hline \multirow[b]{3}{*}{ Treatment } & \multicolumn{3}{|c|}{ Tomato yield (lb/plant $)^{\mathrm{z}}$} & \multirow[b]{3}{*}{ Fruit wt $(\mathrm{oz})^{\mathrm{v}}$} \\
\hline & \multicolumn{2}{|c|}{ Marketable } & \multirow[b]{2}{*}{ Cull $^{w}$} & \\
\hline & Early ${ }^{y}$ & Total $^{x}$ & & \\
\hline \multicolumn{5}{|c|}{$P>\mathrm{F}$} \\
\hline Tomato cultivar (C) & $<0.0001$ & $<0.0001$ & 0.0002 & 0.0002 \\
\hline Cluster pruning $(\mathrm{P})$ & 0.5203 & 0.0458 & $<0.0001$ & $<0.0001$ \\
\hline $\mathrm{C} \times \mathrm{P}$ & 0.0184 & 0.2932 & 0.1498 & 0.1670 \\
\hline $\mathrm{C} \times \operatorname{Year}(\mathrm{Y})$ & 0.0041 & 0.2284 & 0.0964 & 0.4127 \\
\hline $\mathrm{P} \times \mathrm{Y}$ & 0.7253 & 0.5866 & 0.0079 & 0.2610 \\
\hline $\mathrm{C} \times \mathrm{P} \times \mathrm{Y}$ & 0.3361 & 0.7254 & 0.2362 & 0.7491 \\
\hline \multicolumn{5}{|l|}{ Tomato cultivar } \\
\hline Geronimo & $\mathrm{na}^{\mathrm{u}}$ & $28.2 \mathrm{a}^{\mathrm{t}}$ & $1.3 \mathrm{~b}$ & $7.9 \mathrm{a}$ \\
\hline Quest & na & $24.3 \mathrm{~b}$ & $1.2 \mathrm{~b}$ & $7.7 \mathrm{a}$ \\
\hline Trust & na & $21.6 \mathrm{c}$ & $2.1 \mathrm{a}$ & $7.3 \mathrm{~b}$ \\
\hline \multicolumn{5}{|c|}{ Cluster pruning (fruit/cluster) } \\
\hline Three & na & $25.4 \mathrm{a}$ & na & $8.0 \mathrm{a}$ \\
\hline Four & na & $24.0 \mathrm{~b}$ & na & $7.3 \mathrm{~b}$ \\
\hline
\end{tabular}

${ }^{\mathrm{z}} 1 \mathrm{lb}=0.4536 \mathrm{~kg}$.

'Early marketable yield is the marketable fruit graded medium or larger in the first five harvests.

${ }^{\mathrm{x}}$ Total marketable yield is the marketable fruit graded medium or larger in all harvests.

${ }^{w}$ Cull yield is the unmarketable fruit.

$\mathrm{v} \mathrm{loz}=28.3495 \mathrm{~g}$.

"Not applicable due to significant interaction effects.

${ }^{t}$ For each tomato cultivar and cluster pruning method, means within columns followed by the same letter are not significantly different at $P \leq 0.05$ by least square means.

early marketable yield in 2007 than in 2006 (Table 2). Pruning clusters to ree fruit reduced cull yield to 0.92 $0.68 \mathrm{lb}$ / plant in 2006 and 2007 respectively. Pruning clusters to four fruit resulted in significantly higher cull yield of 2.00 and $2.69 \mathrm{lb} /$ plant sear's sequence. means indicated that "Geronin produced the highest total marketable yield and 'Trust' produced the lowest. 'Geronimo' and 'Quest' produced lower cull yield and heavier fruit than 'Trust' (Table 1). Pruning clusters to three fruit significantly creased total marketable yield and These results indicated that 'Geronimo' and 'Quest' each produced higher yield than the more popular 'Trust' cultivar. Growers in Louisiana and other southern U.S. states should produce more yield dheavier fruit if they replace 'Trust' either one of the other two it was more productive to prune fruit clusters to three.

All cultivars had similar fruit conble solids concentration (Table 3 ). Potassium is important for fruit

Horllechnology $\cdot$ April-June 2009 19(2)
Table 2. Interaction effects of tomato cultivar and cluster pruning (three or four fruit per cluster) and cultivar and year on early marketable yield of tomatoes in a $30 \times 96-\mathrm{ft}(9.1$ $\times 29.3 \mathrm{~m})$ greenhouse in 2006 and 2007 at Louisiana State University Agricultural Center, Bossier City.

\begin{tabular}{|c|c|c|c|c|}
\hline \multirow{3}{*}{$\begin{array}{l}\text { Tomato } \\
\text { cultivar }\end{array}$} & \multicolumn{4}{|c|}{$\begin{array}{l}\text { Early marketable } \\
\text { yield (lb/plant })^{\mathrm{z}}\end{array}$} \\
\hline & \multicolumn{2}{|c|}{$\begin{array}{l}\text { Cluster } \\
\text { pruning } \\
\text { (fruit/ } \\
\text { cluster) }\end{array}$} & \multicolumn{2}{|c|}{ Year } \\
\hline & Three & Four & 2006 & 2007 \\
\hline Geronimo & $4.7 b^{y}$ & $5.3 \mathrm{a}$ & $3.5 b^{y}$ & $6.5 a$ \\
\hline Quest & $4.3 \mathrm{a}$ & $4.5 a$ & $3.4 b$ & $5.5 \mathrm{a}$ \\
\hline Trust & $3.7 \mathrm{a}$ & $4.0 \mathrm{a}$ & $2.8 \mathrm{~b}$ & $4.9 \mathrm{a}$ \\
\hline
\end{tabular}

quality (Taber et al., 2008) and moderate sodium is important for fruit taste (Snapp and Shennan, 1990). Only 'Trust' produced fruit with higher $\mathrm{pH}$ (Table 3 ).

About $92 \%$ of 'Quest' tomatoes remained marketable after storage for $\mathrm{l}$ week at $67^{\circ} \mathrm{F}$. 'Geronimo' and 'Trust' had only $83 \%$ and $78 \%$ marketable fruit, respectively, after storage for the same period (Table 3 ).

'Geronimo' produced higher yields than 'Quest' in this study, but 'Quest' fruit had a significantly longer shelf life than 'Trust'. 'Quest' fruit also had a shiny color and a marketing edge over 'Geronimo' and 'Trust' (Canadian Greenhouse Conference, unpublished data). 'Trust' fruit had a short shelf life most likely because of minute shoulder cracks that led to moisture loss during storage (Fig. 1). This defect was more common in 'Trust' than in 'Geronimo', and was least common in 'Quest' fruit.

The second study indicated that it was more expensive to grow tomatoes in perlite and least expensive in pine bark (Table 4). Perlite can be recycled for many years to reduce production cost without a negative impact on yield (Hanna, 2005, 2006). Rockwool can be steam-sterilized and reused once and must then be disposed of because of fiber breakdown during steam sterilization and handling (Papadopoulos, 1991). A significant cost is associated with the disposal of rockwool (Straver, 1995). 
Table 3. Analysis of variance and mean separation by least square means for tomato fruit potassium, sodium, $\mathrm{pH}$, soluble solid concentration and shelf life of three tomato cultivars planted in 2006 and 2007 at Louisiana State University Agricultural Center, Bossier City.

\begin{tabular}{|c|c|c|c|c|c|}
\hline \multirow[b]{2}{*}{ Treatment } & \multicolumn{3}{|c|}{ Tomato fruit analyses ${ }^{z}$} & \multirow[b]{2}{*}{$\begin{array}{c}\text { Soluble solids } \\
\text { concn }(\%)\end{array}$} & \multirow[b]{2}{*}{$\begin{array}{l}\text { Shelf } \\
\text { life }^{\mathrm{x}}\end{array}$} \\
\hline & $\begin{array}{c}\text { Potassium } \\
(\mathrm{ppm})^{\mathrm{y}}\end{array}$ & $\begin{array}{c}\text { Sodium } \\
\text { (ppm) }\end{array}$ & $\mathrm{pH}$ & & \\
\hline \multicolumn{6}{|c|}{$P>\mathrm{F}$} \\
\hline Tomato cultivar (C) & 0.7231 & 0.6788 & 0.0036 & 0.3389 & 0.0253 \\
\hline $\mathrm{C} \times$ year & 0.4226 & 0.7575 & 0.2394 & $0.0482^{w}$ & 0.2289 \\
\hline \multicolumn{6}{|l|}{ Tomato cultivar } \\
\hline Geronimo & $1,950 \mathrm{a}^{\mathrm{v}}$ & $31.6 \mathrm{a}$ & $4.3 \mathrm{~b}$ & $4.2 \mathrm{a}$ & $83.2 \mathrm{ab}$ \\
\hline Quest & $1,989 \mathrm{a}$ & $30.9 \mathrm{a}$ & $4.3 \mathrm{~b}$ & $4.3 \mathrm{a}$ & $92.2 \mathrm{a}$ \\
\hline Trust & $1,961 \mathrm{a}$ & $31.6 \mathrm{a}$ & $4.4 \mathrm{a}$ & $4.2 \mathrm{a}$ & $78.1 \mathrm{~b}$ \\
\hline
\end{tabular}

${ }^{z}$ Average of early, mid-, and end of harvest season data. Samples were collected from clusters pruned to three fruit. ${ }^{\mathrm{y}} \mathrm{l} \mathrm{ppm}=1 \mathrm{mg} \cdot \mathrm{L}^{-1}$

${ }^{x}$ Shelf life expressed as percentage of fruit that remained marketable after 1 week storage at $67{ }^{\circ} \mathrm{F}\left(19.4{ }^{\circ} \mathrm{C}\right)$ Samples were collected from clusters pruned to three fruit.

"Although the cultivar $\times$ year interaction is significant $(P=0.0482)$ investigation of the cultivar means showed similar trends within each year and thus it was not necessary to compare the cultivars within each year.

vFor each tomato cultivar, means within columns followed by the same letter are not significantly different at $P \leq$ 0.05 by least square means.

Table 4. Growing media and transplant container costs to plant 640 tomato plants in a $30 \times 96-\mathrm{ft}(9.1 \times 29.3 \mathrm{~m})$ greenhouse at Louisiana State University Agricultural Center, Bossier City, based on 2006 and 2007 retail prices.

\begin{tabular}{lcccr}
\hline & \multicolumn{3}{c}{ Costs $(\$)$} & \\
\cline { 2 - 4 } & Media $^{\mathbf{z}}$ & Grow bags $^{\mathbf{y}}$ & Transplant container $^{\mathbf{x}}$ & Total \\
\hline Perlite & 591.48 & 73.28 & 20.85 & 685.61 \\
Pine bark & 351.92 & 73.28 & 20.85 & 446.05 \\
Rock wool & 461.17 & - & 169.60 & 630.77 \\
\hline
\end{tabular}

${ }^{\mathrm{z}} 212 \mathrm{ft}^{3}$ perlite at $\$ 2.79 / \mathrm{ft}^{3}, 212-\mathrm{ft}^{3}$ pine bark at $\$ 1.66 / \mathrm{ft}^{3}, 107$ rockwool slabs at $\$ 4.31 /$ slab; $1 \mathrm{ft}^{3}=0.0283 \mathrm{~m}^{3}$, $\$ 1.00 / \mathrm{ft}^{3}=\$ 35.3147 / \mathrm{m}^{3}$

${ }^{y}$ Three hundred twenty grow bags at $\$ 0.229 / \mathrm{bag}$ for perlite and same for pine bark media.

${ }^{x}$ Seventeen trays at $\$ 0.68$ /tray plus $1.06 \mathrm{ft}^{3}$ Pro-Mix BX (Premier Horticulture, Quakertown, PA) at $\$ 8.76 / \mathrm{ft}^{3}$ for the perlite and pine bark media; 320 rockwool cubes at $\$ 0.53 /$ cube for the rockwool media.

Properly composted pine bark to grower's specifications is hard to find and was difficult to recycle because it turns to slush as it continues to decompose (H.Y. Hanna, personal observation).

The main effects of growing media and pruning on marketable and cull yields and fruit weight of 'Quest' were significant as indicated by the $\mathrm{F}$ test and mean separation data by least square means in Table 5 . Pruning $\times$ year effect on early marketable yield was the only significant interaction (Table 5). Further interaction data analysis indicated that tomatoes pruned to three fruit per cluster produced 3.85 and $5.69 \mathrm{lb} /$ plant early marketable yield in 2006 and 2007, respectively. Plants pruned to four fruit per cluster produced 3.36 and $5.66 \mathrm{lb} /$ plant in the same year's sequence. These results indicated that early marketable yield was higher in 2007 than in 2006 regardless of the pruning method.
'Quest' plants grown in perlite produced greater total marketable yields than plants grown in pine bark or rockwool. Perlite and rockwool grown plants produced similar early marketable yields, which was higher than the early marketable yield of pine bark-grown plants. Rockwool-grown plants produced significantly higher cull yield than perlite- and pine barkgrown plants (Table 5). Szmidt et al. (1988) reported that greenhouse tomatoes grown in perlite produced higher yield than those grown in rockwool. Snyder (1995) indicated that tomatoes grown in pine bark in Mississippi produced equal or superior yields to plants grown in rockwool. Results of the current studies indicated that tomatoes grown in pine bark or rockwool produced similar total marketable yields.

Cluster pruning to three fruit significantly increased total marketable yield, reduced cull yield, and increased fruit weight (Tables 5). Previous pruning recommendations ranged from three to five fruit per cluster (Hochmuth, 1991; Ministry of Agriculture, Food, and Rural Affairs, 2001; Papadopoulos 1991; Snyder, 2001).

\section{Conclusion}

'Geronimo' or 'Quest' produced higher total marketable yields than 'Trust' in this study and should be considered by growers in the southern states. It is recommended growers start on a small scale first because of possible environmental effects. 'Geronimo' should be considered for its higher yield, and 'Quest' for its adequate yield and shiny fruit that has superior shelf life.

Few greenhouse cultivars are released each year, and knowledge about their performance is extracted from the description released by the breeder company. Many smaller growers, particularly new ones, depend on communications with established growers to choose a cultivar. Case in point, 'Trust' was more popular in southern states than any other cultivar because of grower interaction during workshops. This study indicated that 'Geronimo' and 'Quest' can be appropriate alternative to 'Trust' and can help growers produce more yield per unit area and extend fruit shelf life. 'Geronimo's' higher yield can compensate for its short shelf life.

Rockwool is probably the most common substrate for soilless culture, but it requires frequent replacement at a significant cost for the grower. Pine bark is locally available at a low cost, but adequately composted pine bark to grower's specifications is hard to acquire and frequent replacement can be labor intensive and time consuming. This study indicated that tomatoes grown in perlite produce higher yields that can make up for some of the initial cost of the media. Perlite can be recycled successfully for many years to reduce production expense in following years. Properly recycled perlite can save money, time, and natural resources, and can reduce worker fatigue arising from removing and replacing the old medium with a new one.

Tomato growers were not persuaded to prune clusters to an exact number of fruit because of the conflicting reports about the optimum number of fruit that can lead to 
Table 5. Analysis of variance and mean separation by least square means for tomato marketable and cull yields and fruit weight of cultivar Quest grown in 2006 and 2007 as related to treatment effect in a $30 \times 96-\mathrm{ft}(9.1 \times 29.3 \mathrm{~m})$ greenhouse at Louisiana State University Agricultural Center, Bossier City.

\begin{tabular}{|c|c|c|c|c|}
\hline \multirow[b]{3}{*}{ Treatment } & \multicolumn{3}{|c|}{ Tomato yield (lb/plant $)^{\mathrm{z}}$} & \multirow[b]{3}{*}{ Fruit wt $(\mathrm{oz})^{\mathrm{v}}$} \\
\hline & \multicolumn{2}{|c|}{ Marketable } & \multirow[b]{2}{*}{ Cull $^{w}$} & \\
\hline & Early $^{\mathrm{y}}$ & Total $^{\mathrm{x}}$ & & \\
\hline \multicolumn{5}{|c|}{$P>\mathrm{F}$} \\
\hline Growing media $(\mathrm{M})$ & 0.0279 & 0.0156 & 0.0101 & 0.0547 \\
\hline Cluster pruning $(\mathrm{P})$ & 0.0327 & 0.0015 & $<0.0001$ & $<0.0001$ \\
\hline $\mathrm{M} \times \mathrm{P}$ & 0.7782 & 0.3210 & 0.2292 & 0.2775 \\
\hline $\mathrm{M} \times \operatorname{Year}(\mathrm{Y})$ & 0.1230 & 0.1970 & 0.1782 & 0.2676 \\
\hline $\mathrm{P} \times \mathrm{Y}$ & 0.0535 & 0.7958 & 0.3163 & 0.3299 \\
\hline $\mathrm{M} \times \mathrm{P} \times \mathrm{Y}$ & 0.7641 & 0.4770 & 0.9920 & 0.9319 \\
\hline \multicolumn{5}{|l|}{ Growing media } \\
\hline Perlite & $4.8 \mathrm{a}^{\mathrm{u}}$ & $23.6 \mathrm{a}$ & $1.8 \mathrm{~b}$ & $7.4 \mathrm{ab}$ \\
\hline Pine bark & $4.4 \mathrm{~b}$ & $21.9 \mathrm{~b}$ & $2.0 \mathrm{~b}$ & $7.5 \mathrm{a}$ \\
\hline Rock wool & $4.7 \mathrm{a}$ & $21.1 \mathrm{~b}$ & $2.5 \mathrm{a}$ & $7.2 \mathrm{~b}$ \\
\hline \multicolumn{5}{|c|}{ Cluster pruning (fruit/cluster) } \\
\hline Three fruit & $\mathrm{na}^{\mathrm{t}}$ & $23.3 \mathrm{a}$ & $0.9 \mathrm{~b}$ & $7.8 \mathrm{a}$ \\
\hline Four fruit & na & $21.0 \mathrm{~b}$ & $3.2 \mathrm{a}$ & $6.9 \mathrm{~b}$ \\
\hline
\end{tabular}

${ }^{\mathrm{z}} 1.0 \mathrm{lb}=0.4536 \mathrm{~kg}$.

'Early marketable yield is the marketable fruit graded medium or larger in the first five harvests.

${ }^{x}$ Total marketable yield is the marketable fruit graded medium or larger in all harvests.

${ }^{w}$ Cull yield is the unmarketable fruit.

${ }^{\mathrm{v}} 1.0 \mathrm{oz}=28.3495 \mathrm{~g}$.

"For each media and cluster pruning method, means within columns followed by the same letter are not significantly different at $P \leq 0.05$ by least square means.

${ }^{t}$ Not applicable due to significant interaction effects.

higher yields and heavy fruit. The present studies indicated that fruit was heavier and plants produced more marketable yield and less cull yield if only three fruit were left on each cluster.

We encourage smaller growers in Louisiana and other states to consider the current recommendations and others from our previous research, i.e., plant 'Geronimo' or 'Quest', prune clusters to three fruit, use perlite as growing media, and recycle perlite properly. These recommendations can help the local producer survive serious competition from imported greenhouse tomatoes.

\section{Literature cited}

Demers, D., M. Dorais, and A.P. Papadopoulos. 2007. Yield and russeting of greenhouse tomato as influenced by leafto-fruit ratio and relative humidity. HortScience 42:503-507.

Hanna, H.Y.Greenhouse tomato manual. 2003. 24 June 2008. <http:// www.lsuagcenter.com/en/lawn_garden/ commercial_horticulture/greenhouse_ production/Greenhouse+Tomato+ Production+Manual.htm>.

Hanna, H.Y. 2005. Properly recycled perlite saves money, does not reduce greenhouse tomato yield, and can be reused for many years. HortTechnology $15: 342-345$.

Hanna, H.Y. 2006. A stir and disinfect technique to recycle perlite for costeffective greenhouse tomato production. J. Veg. Sci. 12(1):51-63.

Hanna, H.Y. and K.D. Henderson. 2002. Modifying greenhouse heating systems to reduce energy cost and produce more tomatoes. Louisiana Agr. 45(3):10-11.

Hanna, H.Y. and K.D. Henderson. 2008. Fuel type and releasing the heated air near plant roots reduce production cost of greenhouse tomatoes. HortTechnology 18:290-294.

Hochmuth, R.C. 1991. Production of greenhouse tomatoes. p. 33-45. In: G. Hochmuth (ed.). Greenhouse vegetable production handbook, Coop. Ext. Serv., Univ, Florida, Gainesville.
Korevaar, S. 2007. Greenhouse market in the USA. Practical Hydroponics Greenhouses March/April:34-35.

Maynard, D.N. and S.M. Olson. 2002. Variety selection, one of the most important management decisions, Tomato Mag. June:20-21.

Ministry of Agriculture, Food, and Rural Affairs. 2001. Cluster pruning, p. 46Growing greenhouse vegetables. Publ. 371. Ministry Agriculture and Food Rural Affairs, Toronto, Canada.

Morgan, L. 2001. Measuring fruit quality and fruit quality testing by grower, Tomato Mag. August:12-15.

Newsom, D.W. 1961. Ripen tomatoes under controlled conditions. Louisiana Agr. 4(3):6-7.

Papadopoulos, A.P 1991. Growing greenhouse tomatoes in soil and in soilless media. Publ. 1865/E. Communications Branch, Agriculture and Agri-food Canada, Ontario, Canada.

Snapp, S. and C. Shennan. 1990. Tomato fruit quality and ion status: The effects of salinity, phytophthora root rot and genotype. HortScience 25:1149. (Abstr).

Snyder, R.G. 1995. Greenhouse tomatoesthe basics of successful production, p. 3-6. In: Proc. Greenhouse Tomato Seminar. ASHS Seminar Ser American Society for Horticultural Science Press, Alexandria, VA.

Snyder, R.G. 2001. Greenhouse tomato handbook. Mississippi State Univ. Ext. Serv. Publ. 1828.

Straver, W.A. 1995. Inert growing media for greenhouse tomatoes, p. 1315. In: Proc. Greenhouse Tomato Seminar. ASHS Seminar Ser., American Society for Horticultural Science Press, Alexandria, VA.

Szmidt, R.A.K., D.A. Hall, and G.M. Hitchon. 1988. Development of perlite culture system for the production of greenhouse tomatoes. Acta Hort. 221:371-378.

Taber, H., P. Perkins-Veazi, S. Li, W. White, S. Rodermel, and Y. Xu. 2008. Enhancement of tomato fruit lycopene by potassium is cultivar dependent. HortScience 43:159-165.

U.S. Department of Agriculture. 1997. United States standards for grades for fresh tomatoes. Agr. Mkt. Serv. 7 CFR 51. 